\title{
O Desenvolvimento \\ da Agroindústria Canavieira do Brasil desde a Segunda Guerra Mundial*
}

\section{TAMÁS SZMRECSÁNYI**}

\section{e EDUARDO PESTANA MOREIRA***}

A situação atual da agroindústria canavieira do Brasil é, para dizer o mínimo, extremamente complicada. Seus dois principais produtos, o açúcar e o álcool, estáo ambos enfrentando crescentes problemas de comercialização. As dificuldades relativas ao açúcar não são apenas brasileiras, mas mundiais. Tendo-se transformado, desde a Segunda Guerra, essencialmente numa matéria-prima industrial, ele se encontra atualmente às voltas com uma concorrência cada vez maior da parte de diversos sucedâneos naturais e sintéticos - tais como a isoglucose de milho, ou HFCS, e o aspartame - os quais estão subtraindo parcelas consideráveis de sua antiga demanda. Já os problemas do álcool são, estes sim, peculiares e específicos ao Brasil, já que nosso país tem sido até agora o único a tentar transformar esse produto num substituto da gasolina automotiva. De um ponto de vista social e macroeconômico, essa tentativa vem sendo um completo malogro; em nossa opiniáo, se o álcool tivesse permanecido, como antes e alhures (nos Estados Unidos, por exemplo), um mero aditivo à gasolina, os atuais problemas energéticos do país seriam mais facilmente solucionáveis (1).

Este trabalho foi escrito na suposição de que o conhecimento pode ser importante para a soluçáo dos problemas, e de que uma maneira de contribuir neste sentido reside na análise das origens e da evolução histórica dos mesmos. Por outro lado, ele pretende também ser a continuação de um trabalho anterior, apresentado na prévia conferência (2). Devido ao fato do mesmo se basear em nossos próprios trabalhos aca-

\footnotetext{
* Traduçáo feita pelos autores do paper apresentado na conferência The International Sugar Economy, 1945-1990, realizada entre 29 e 31 de agosto de 1990, na Universidade de East Anglia, em Norwich, Inglaterra.

* Tamás Szonrecsanyi é professor do Departamento de Política Científica e Tecnológica do Instituto de Geociências da Unicamp.

** Eduardo Pestana Moreira é pesquisador do Agrupamento de Economia em Tecnologia do Instituto de Pesquisas Tecnológicas de São Paulo.
} 
dêmicos (3), achamos preferivel omitir quaisquer outras notas e referências bibliográficas, acrescentando em vez delas as quatro tabelas estatísticas colocadas ao final do texto. Essas tabelas proporcionam uma visão de conjunto do desenvolvimento da produçáo brasileira de cana, açúcar e álcool nestes últimos cinquenta anos, assim como da cambiante distribuiçấo espacial da primeira após o término da última guerra mundial. O nosso relato é essencialmente cronológico, cobrindo quatro fases seqüênciais.

\section{A Segunda Guerra Mundial e os seus Efeitos (1939-1949)}

A eclosão da II Guerra Mundial criou para a agroindústria canavieira do Brasil uma situaçăo bem diversa da que havia prevalecido durante e imediatamente após o conflito de 1914-18. Contrariamente ao que teria sido de se esperar, ela não provocou um aumento das exportações de açúcar. Em compensação, a guerra de 1939-45 deu origem a algumas dificuldades que, embora năo tivessem sido completamente inesperadas, deixaram de ser previstas com a precisáo que teria sido necessária para se poder evitá-las de uma forma mais satisfatória.

Uma dessas dificuldades eram os riscos do transporte marítimo em decorrência da guerra submarina. Tais riscos, que tinham sido muito menos intensos durante a I Guerra Mundial, foram um dos principais fatores subjacentes ao declínio das exportaçóes de açúcar naqueles anos. O volume das mesmas diminuiu de um total de 226,5 mil toneladas métricas (TM) entre 1935 e 1939, nos últimos anos da depressão antes da guerra, para 218,2 mil TM no quinquiênio seguinte. Uma boa parte dessas últimas exportaçóes foi destinada aos países vizinhos da América do Sul e, a rigor, a única vantagem derivada das condiçóes de guerra residiu na alta dos preços do produto. Graças a ela, o Instituto do Açúcar e do Álcool (IAA), que fora criado em 1933, pôde parar de ter prejuízo com as exportaçōes de açúcar, um monopólio que ele manteria praticamente até o final de sua longa existência.

As dificuldades no transporte marítimo afetaram não apenas o volume das exportaçóes do Brasil, e o das suas importaçōes, mas também o volume do seus produtos transportados por cabotagem. A navegação costeira tinha naquela época uma importância muito maior do que hoje, devido às deficiências da rêde de transportes internos então existentes. Uma boa parte do comércio interno de mercadorias entre o norte e o sul do país ainda era feita por seu intermédio, e um dos produtos mais afetados pela guerra submarina foi precisamente o açúcar, cujo abastecimento interno dependia fundamentalmente da produção nordestina, enquanto que os seus principais centros consumidores se achavam localizados no Centro-Sul, mais particularmente nas cidades dos Estados do 
Rio de Janeiro e de Sáo Paulo. Um dos primeiros e principais efeitos do conflito foi o de ter cortado o país em duas partes, com uma vendo-se repentinamente à frente de uma grande superproduçáo de açúcar, e a outra passando a sofrer uma crescente escassez do mesmo produto.

Essa demanda insatisfeita dos principais centros consumidores criou as condiçóes necessárias para a expansão da produção de açúcar em regióes que anteriormente o importavam de outras, basicamente do Nordeste. E foi essa expansão dos anos da Segunda Guerra que deu origem à definitiva trasnferência do eixo da produção canavieira e açucareira para os Estados do sudeste do Brasil, uma transferência que só chegou a se completar de fato na década de 1950 , mas que já podia ser percebida ao término do conflito.

Uma questáo que pode ser lavantada refere-se às medidas que efetivamente foram adotadas pelo IAA para enfrentar essa nova siutaçáo. Nossa resposta a ela é que esse órgão de regulação estatal, embora com atraso, fez o que pôde para lidar com os acontecimentos, mas foi literalmente avassalado por eles, tanto em relação ao açúcar quanto ao álcool.

A produçáo deste havia sido consideravelmente ampliada durante a década de 1930. Isto se aplica particularmente ao álcool anidro, usado como aditivo à gasolina, cuja fabricação tinha sido iniciada em 1933 numa destilaria estatal localizada em Campos, no Estado do Rio de Janeiro, e dotada de uma capacidade conjunta de $\mathbf{4 3 7}$ mil litros por dia, e uma produçáo efetiva de 38 milhóes de litros naquele ano. Em 1941, esses números tinham aumentado, respectivamente, para 44 destilarias, uma capacidade diária de 638 mil litros, e uma produção efetiva de quase 77 milhóes de litros - ou seja, mais do que o dobro do nível alcançado dois anos antes.

Toda essa expansão se deveu fundamentalmente aos incentivos financeiros e administrativos do Instituto, e em parte também aos seus próprios investimentos no setor, através da implantaçáo e operação das chamadas destilarias centrais de sua propriedade. Estas destilarias não eram particularmente vinculadas a qualquer usina, mas estavam aparelhadas para processar a matéria-prima (basicamente melaço) encaminhada por aquelas que não tivessem destilaria própria, ou cujas destilarias fossem pequenas demais. A destilaria central que acaba de ser mencionada foi logo seguida pela implantação de duas outras, respectivamente nos Estados de Pernambuco e de Minas Gerais.

Entre os principais incentivos às destilarias particulares, todas anexas a determinadas usinas, pode-se mencinar: o aumento da proporçáo de álcool anidro a ser adicionado à gasolina importada, de 5 para 20 por cento; a reserva, a partir de 1942 , da maior parte da matéria-prima 
agrícola (cana-de-açúcar) para a produção "direta" de álcool (isto é, a partir do caldo de cana, e não mais com base no melaço residual da fabricaçáo de açúcar); e o estabelecimento de atrativos preços mínimos para o produto.

Tais incentivos não tiveram, entretanto, os resultados que deles se esperavam. A produçáo de álcool, na verdade, especialmente a do álcool anidro chegou a diminuir a partir de 1943 , só voltando a seus níveis anteriores depois que a guerra já tinha acabado, quando sua necessidade se tornara bem menos premente. A principal razão desse declínio da producão (e do consumo) de álcool anidro vinculava-se à falta de oferta no país de produtos desidratantes, como o benzol, os quais eram todos importados naquela época, e que tiveram que deixar de sê-lo por causa da guerra. Mas, a reduçáo da produçáo total de álcool (anidro mais hidratado) era também devida a outros fatores, notadamente à pressáo da demanda interna de açúcar, determinada pelas dificuldades há pouco assinaladas no transporte de cabotagem do Nordeste para o sul do País. Devido a essas dificuldades, o IAA não teve outra opção que a de começar a incentivar a produção de açúcar no Centro-Sul, particularmente nos Estados do Rio de Janeiro e de Sáo Paulo, reduzindo com isto ao mesmo tempo o potencial da produção de álcool dos mesmos.

As medidas tomadas neste sentido determinaram, a médio e longo prazos, um grande aumento da capacidade produtiva instalada nos referidos Estados. Tratava-se de uma tendência que já vinha de antes, e que havia sido interrompida, no início da década de 1930, pelas políticas entáo adotadas pelo próprio Instituto, de proteçáo e amparo à agroindústria canavieira do Nordeste. Ela iria se intensificar bastante após a Segunda Guerra e, mais particularmente, depois da derrubada do Estado Novo, que havia sido instaurado por Getúlio Vargas em 1937. Nos anos de 1945 e 1946, houve várias tentativas, especialmente da parte dos maiores usineiros de São Paulo, para eliminar a intervenção estatal na agroindústria canavieira, e para fechar o IAA (algo que só acabaria em 1990, no início do atual governo).

As referidas tentativas deixaram de ser bem sucedidas naquela época devido à oposiçăo, e à força política, dos produtores de açúcar do Nordeste e do Estado do Rio, desejosos de manterem a sua lucrativa participaçáo no abastecimento do crescente, e cada vez mais próspero, mercado consumidor paulista. Em decorrência da atuação daqueles grupos empresariais, a intervençáo do Estado no setor e o próprio Instituto puderam ser mantidos, não obstante o liberalismo prevalecente naqueles anos, que testemunharam o fechamento, não apenas da importante coordenação de Mobilização Econômica, um órgão de planejamento que fora criado durante a Guerra pelo governo federal, mas também do todo-poderoso Departamento Nacional do Café, o qual durante vários anos havia controlado as exportaçóes e a produção da rubiácea. 
Mas, a preservaçáo do IAA também se tornara possível graças ao substancial aumento que ele havia promovido nas quotas de produçáo de açúcar, um aumento pelo qual os usineiros de Sáo Paulo tiveram incrementada a sua participação no mercado nacional de 17,6 para 22,2 por cento do total, enquanto que os de Pernambuco viam diminuída a sua de 37,7 para 28,9 por cento. Essa medida constituia, de um lado, um reconhecimento formal da gradativa tranferência da hegemonia na agroindústria canavieira do Nordeste para o Centro-Sul. mas, do outro, acabou dando origem a uma renovada $e$ irrefreável tendência à superproduçáo, gerando efeitos que iriam perdurar por várias décadas, chegando até os nossos dias.

É verdade que o consumo interno de açúcar do Brasil havia aumentado consideravelmente desde a década de 1930, graças ao crescimento da populaçáo do país, a aceleração dos seus processos de urbanização e de industrialização, e à elevação de seus níveis de renda per capita. Ocorre, porém, que tanto a produção como, principalmente, a capacidade produtiva do setor tiveram uma expansão ainda mais rápida, particularmente durante e logo após a guerra. Além de tentar controlar essa expansão, algo que não parecia politicamente viável na época, haveria apenas duas maneiras de enfrentar a situaçáo: através do aumento das exportaçóes brasileiras de açúcar, ou mediante a expansão da produção de álcool no país. Ambas foram tentadas pelo IAA, mas apenas a primeira teve algum êxito a curto prazo.

As exportaçóes brasileiras de açúcar cresceram substancialmente nos anos do imediato pós-guerra. Contudo, a progressiva normalizaçáo da produção européia e do comércio internacional logo começaram a minar os preços do produto, forçando o governo do país a voltar a subsididar suas vendas externas. A fim de reduzir o montante desses subsídios e, ao mesmo tempo, procurar melhorar o perfil deficitário da balança comercial, mediante a diminuiçáo das importaçóes de petróleo e seus derivados, o Instituto procurou de várias formas incentivar a produção nacional de álcool, particularmente do álcool anidro a ser adicionado à gasolina. Essa política, no entanto, era dificultada pelos baixos preços do petróleo no mercado internacional, e acabaria sendo inteiramente abandonada no início da década de 1950, coma criação da Petrobrás e a implantação de suas primeiras refinarias.

Uma das principais características daqueles anos do imediato pósguerra foi o estabelecimento de várias novas usinas de açúcar, particularmente no Estado de Sáo Paulo. A maioria delas era constituída por antigos engenhos, que haviam sido instalados durante a Segunda Guerra para atender prementes necessidades de consumo local, momentaneamente desabastecidas pelas suas habituais fontes de suprimento localizadas no Nordeste. A escala de produçáo dessas novas unidades era muito 
pequena, inclusive pelos padróes locais. Seus altos custos de produção e seus baixos níveis de produtividade só se haviam tornado viáveis graças aos elevados preços do açúcar e do álcool fixados pelo IAA durante a Guerra. Esses preços, que se baseavam nos custos de produçáo e de transporte dos usineiros do Nordeste, eram mais do que satisfatórios para produtores localizados em outras áreas do território nacional, mais próximas dos principais centros de consumo, proporcionando-lhes um forte incentivo para constatemente incrementarem seus níveis de produção e de capacidade instalada.

\section{Tentativas de Reinserção no Mercado Internacional (1950-1968)}

A década de 1950 transcorreu sob o signo de uma forte expansão da indústria açucareira do Brasil. Essa expansão foi parcialmente induzida pela crescente demanda do mercado interno, cujas dimensóes estavam sendo gradativamente ampliadas por um rápido e intenso processo de urbanização e de industrialização. Mas, ela também foi muito além, com a produçáo brasileira de açúcar amplamente excedendo o seu consumo interno, fato que determinou um quase imediato retorno do país ao grupo dos maiores exportadores do produto, do qual deixara de participar havia várias décadas.

Essa evolução foi acompanhada de perto, e algumas vezes ativamente promovida pelo IAA, que recebeu na época uma nova estrutura administraiva - maior, mais complexa, e melhor equipada para desincumbir-se das suas crescentes atribuiçóes. Ao mesmo tempo, todavia, embora a performance do Instituto tivesse estado longe de ser negativa naqueles anos, também acabou sofrendo algumas rumorosas derrotas. $\mathrm{Na}$ primeira parte daquela década, por exemplo, ele tentara novamente, mas sem qualquer êxito, reforçar o poder de concorrência dos produtores de açúcar do Nordeste no abastecimento dos ricos e crescentes mercados internos do Centro-Sul. Outro malogro retumbante foi a sua tentativa de canalizar uma parte da produçáo nacional de aguardente para a fabricação de álcool anidro.

De qualquer forma, no início da década de 1950, não havia ainda maiores preocupaçóes quanto aos perigos de um ressurgimento da superproduçáo de açúcar no Brasil. Os eventuais excedentes podiam ser facilmente eliminados através de crescentes exportaçóes, mediante a utilização da matéria-prima para produzir álcool "direto", ou por meio do aumento da estocagem de açúcar em regiōes que estivessem momentaneamente menos bem-abastecidas. Com relação ao álcool, surgira na época um aumento de sua demanda, tanto para utilização como combustível auxiliar (álcool anidro) da crescente frota de autoveículos do 
país, como sob a forma de matéria-prima, requerida pela expansão de vários ramos industriais que o usavam com insumo em seus produtos.

Em fevereiro de 1952, o IAA elevou o nível global da produçáo de açúcar para 36,7 milhóes de sacos de 60 quilos, um nível programado para ser atingido na safra de $1956 / 57$. Esse aumento foi o rompimento, de uma série que iria levar a agroindústria canavieira do Brasil para o seu excesso de capacidade produtiva estrutural do pós-guerra. Ele fora concedido pelo Instituto para aplacar os protestos dos produtores de açúcar do Centro-Sul, particularmente os dos usineiros de São Paulo, contra o seu objetivo de estabelecer uma política de preços diferenciados, a fim de tentar reforçar a capacidade competitiva dos seus concorrentes do Nordeste.

A situaçăo resultante dessa medida passou a requerer crescentes esforços para promover a exportaçáo de excedentes cada vez maiores, uma tarefa cuja dificuldade só fez aumentar com a assinatura, em 1953, do primeiro Acordo Internacional do Açúcar do pós-guerra. A superproduçáo dessa mercadoria voltara a constituir uma tendência universal e, por causa disso, os preços praticados no mercado livre mundial eram extremamente baixos. Devido a essas dificuldades, o Brasil chegou inclusive a se retirar do Acordo em meados da década de 1950, tentando colocar os seus excedentes no exterior a preços rebaixados, sem maior êxito entretanto.

As coisas só não se tornaram piores graças à baixa produção na safra de 1956/57. Apesar desse alívio temporário, a crise continuava suficientemente profunda para revelar a extensáo das distorçóes provocadas pelas políticas governamentais de excessiva proteçáo à agroindústria canavieira do país. Tais distorçóes, na verdade, estavam se tornando recorrentes, e a continuidade delas através do tempo permite explicar muitos dos atuais problemas do setor.

Uma dessas distorçōes era a excessiva generosidade dos financiamentos à comercialização do açúcar, em contraposição às operaçóes de crédito destinadas a custear melhorias nos seus níveis de produtividade agrícola e industrial. Outras vinculavam-se aos grandes aumentos de preços garantidos aos produtores, usualmente bem superiores às taxas de inflação, a fim de assegurar a sobrevivência dos menos eficientes. Todas elas, como seria de se esperar, constituiam fortes estímulos para perpetuar a tendência à superproduçáo.

Na segunda metade da década de 1950, a distribuiçáo das quotas oficiais de produção finalmente levou em conta a nova realidade da agroindústria canavieira que emergira durante a guerra. Os produtores do Centro-Sul, especialmente os do Estado de São Paulo, foram pela primeira vez autorizados a aumentarem suas capacidades instaladas de 
acordo com a evolução dos mercados regionais por eles abastecidos, enquanto que os excedentes de açúcar do Nordeste passaram a ser preferencialmente destinados à exportação. Essa mudança de política do Instituto, junto com as distorçóes que acabam de ser assinaladas, iria contribuir poderosamente para promover uma contínua expansão da produção de açúcar e do cultivo da cana, bem como para encorajar a constante ampliação da capacidade produtiva das usinas, cujos níveis já haviam ultrapassado de muito a capacidade de absorçáo dos mercados internos, tanto de açúcar como do álcool.

Outro problema que também começou a ser percebido naquela época vinculava-se aos altos custos e à baixa produtividade do setor em termos internacionais. Essa defasagem obrigava o governo a subsidiar a maioria das exportações de açúcar. O crescente pêso desses subsídios, cujos valores aumentavam com os volumes exportados, levou o IAA, em 1959, a constituir um grupo de estudos para elaborar propostas relativas às mudanças necessárias para melhorar a situação vigente. Contudo, a maioria das recomendaçóes desse grupo de técnicos só veio a ser adotada vários anos mais tarde, durante e em consequiência de uma grave crise de superproduçăo.

A demora em questão se deveu fundamentalmente à eclosão, naquela mesma época, da Revoluçáo Cubana, seguida, no início da década de 1960 pelo rompimento de relaçóes entre Cuba e os Estados Unidos, e pela exclusão das exportaçóes de açúcar daquele país do mercado preferencial norte-americano. Esses eventos tiveram o dom de alterar por completo a política do governo brasileiro $\mathrm{em}$ relaçáo à agroindústria canavieira. Tratava-se em parte de uma decorrência do fato do Brasil ter obtido, pela primeira vez naquela ocasião, um acesso substancial a esse mercado protegido e de preços mormalmente mais altos que os do mercado livre mundial. Mas, a radical mudança de política então empreendida foi também causada pelas grandes (e infundadas) expectativas do Brasil vir a poder substituir toda a produçáo cubana destinada àquele mercado. $O$ fato de que dezenas de outros países produtores de açúcar também estavam começando a ter acesso a ele na mesma época não chegou a ser devidamente levado em conta.

Um fator adicional para esse repentino surto de otimismo vinculava-se à filiação de Cuba ao Bloco Socialista liderado pela URSS, país do qual a ilha do Caribe logo se transformou no principal fornecedor de açúcar. A grande e crescente demanda daquele imenso mercado preferencial, somada às dificuldades de Cuba em rapidamente ampliar a sua produção, por razōes de ordem climática e de outra natureza, estava também abrindo um novo espaço no mercado livre mundial, do qual aquele país sempre fora um dos maiores exportadores.

Essas perspectivas de uma demanda crescente de açúcar tanto pelo 
Ilistrafã̃o de Candido Portinari: Lavoura de cana, óleo/madcira, $46 x$ $54 \mathrm{~cm}, 1948$ Extraída de Ciência Hojc, Vol. 9, N.

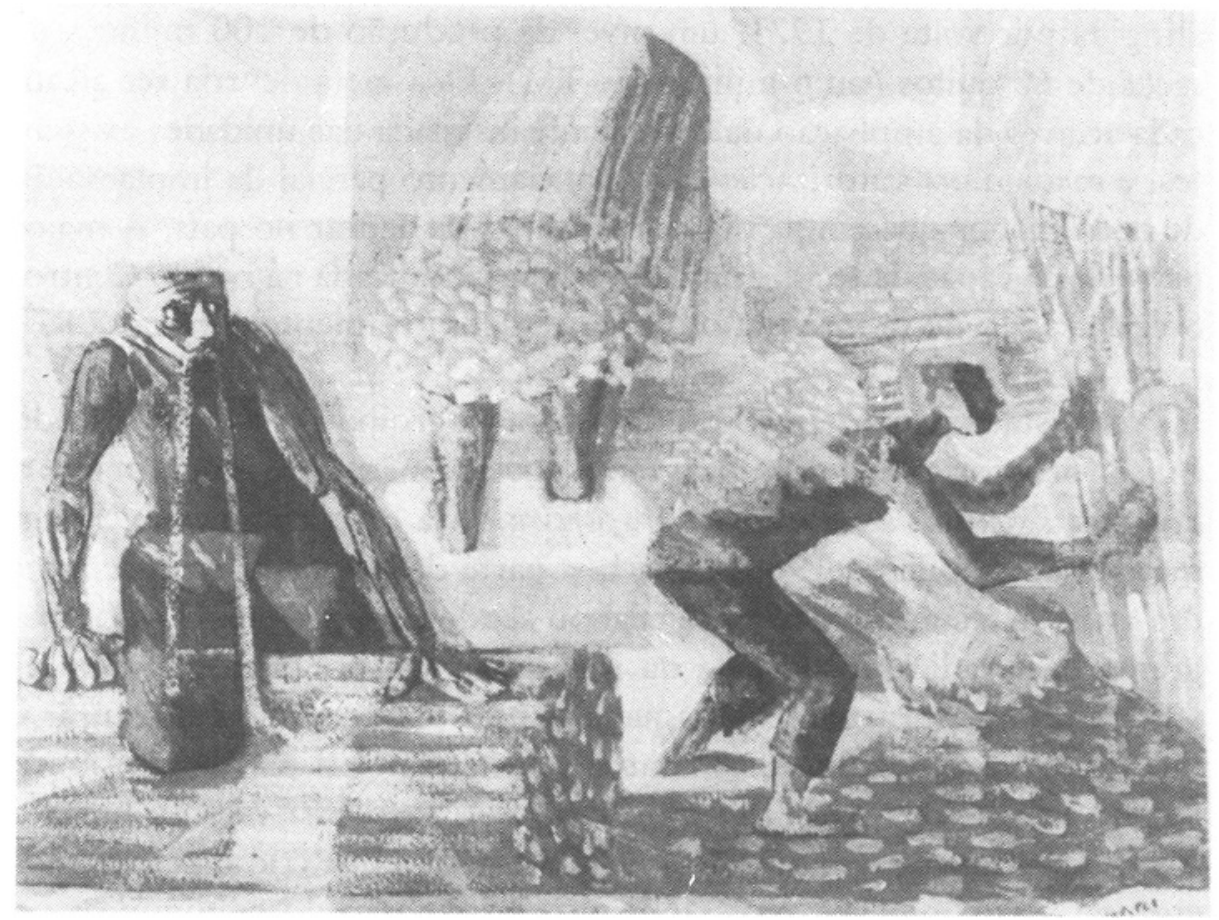

mercado livre mundial como pelo mercado preferencial dos Estados Unidos levaram o IAA a conferir a mais alta prioridade ao abastecimento dos mercados externos e a estabelecer em consequiência, no ano de 1961, uma nova e poderosa Divisão de Exportação. Pelas mesmas razões, os controles governamentais até então prevalecentes sobre a produção, os quais, por sinal, já haviam deixado de funcionar satisfatoriamente, foram não apenas relaxados, mas plenamente transformados em incentivos à produção. Créditos subsidiados de longo prazo começaram a ser concedidos à agroindústria canavieira, com o objetivo de ampliar a produçáo de açúcar e de cana. O propósito deste e de outros incentivos adotados na época era o de fazer voltar o Brasil à liderança mundial da produçáo e das exportaçóes de açúcar. Estas últimas deixaram de ser encaradas como simples expediente para garantir a manutenção de altos níveis de produção, de preços e de lucros na agroindústria canavieira do país. Elas se tornaram ipso facto um objeto em si mesmo.

Uma tão completa reversão das políticas anteriores só poderia alcançar a mais entusiástica acolhida por parte dos produtores de açúcar do país. Dentro desse clima, as lideranças empresariais da agroindústria canavieira elaboraram em 1962 um documento endereçado à presidência do IAA, no qual projetavam uma demanda (interna e externa) de 80 a 90 milhóes de sacos de açúcar para 1970, e solicitavam ao Governo a autorização e os meios financeiros necessários para expandirem em mais de $50 \%$ a capacidade produtiva então instalada. Tais reivindicaçóes foram integralmente acolhidas pelas autoridades governamentais, e se transformaram em componenetes fundamentais da orientação do próprio Instituto. Devido a isso, ele acabou estabelecendo, como meta a ser 
atingida por volta de 1971 , um nível de produção de 100 milhóes de sacos de 60 quilos (ou 6 milhóes de TM). Essa meta deveria ser alcançada através da ampliaçáo da capacidade instalada das unidades existentes, e mediante a autorização e o financiamento parcial da implantaçáo de nada menos que cinquenta novas usinas de açúcar no país. A maior parte dessa capacidade adicional deveria ser localizada na regiáo CentroSul, deixando desta maneira o Nordeste definitivamente para trás.

A vasta expansão entáo prevista para a agroindústria canavieira do Brasil foi incorporada num programa governamental de longo prazo, 0 Plano de Expansáo da Indistria Afucareira, cuja execuçáo teve início em meados da década de 1960. Uma boa parte dos recursos financeiros e das áreas necessárias para tanto acabou sendo proporcionada pelo programa de erradicaçáo do café da mesma época, por meio do qual as autoridades governamentais daquele tempo pretendiam reestruturar e modernizar a cafeicultura, uma atividade tradicional mas entáo pouco lucrativa dentro da economia brasileira. Foi, aliás, esse mesmo programa de substituição e de reorganização de cultura que criou, pelo menos em parte, as condiçóes necessárias para a expansão do cultivo da soja, um produto do qual o Brasil náo tardaria a se transformar num dos principais exportadores mundiais.

Paralelamente a esses eventos, no início da década de 1960, novos mercados estavam também sendo procurados para o previsível acréscimo na produção de álcool do país. Como é bem sabido, este produto pode ser obtido diretamente do caldo da cana, ou residualmente a partir do melaço derivado do produçáo de açúcar. Como esta última iria ser consideravelmente aumentada, uma demanda adicional deveria também ser prevista para o álcool. $O$ uso deste como aditivo à gasolina foi reduzido na época pela expansão da capacidade de refino da Petrobrás. Uma das alternativas entáo preconizadas era a de ampliar a utilização do álcool como matéria-prima pela indústria química. Ele poderia ser utilizado, por exemplo, na fabricaçăo de borracha sintética pela Coperbo, uma empresa estatal que estava sendo instalada em Recife. Outra possibilidade era a de exportar o melaço, principalmente para os EUA, onde esse produto vinha sendo crescentemente empregado como importante componente da alimentaçăo animal.

Todos esses estudos e projetos foram, porém, abruptamente interrompidos pela eclosão de uma nova $e$ intensa crise de superproduçáo, cujo impacto atingiu a agroindústria canavieira do Brasil na segunda metade dos anos 60 . Os primerios sintomas dessa crise já haviam surgido em 1964, com um forte declínio dos preços do açúcar no mercado livre mundial, um declínio que náo poderia ser compensado pelos preços mais favoráveis que vigoravam no mercado preferencial norte-americano. A redução da demanda e dos preços do açúcar nos mercados inter- 
nacionais coincidiu no tempo com a forte recessão instaurada no mercado interno do Brasil, em decorrência da política econômica da então recém-inaugurada ditadura militar.

As exportaçóes de açúcar haviam sido demasiadamente ampliadas nos anos anteiores e não podiam mais ser utilizadas como válvulas de segurança para escoar os excedentes da produção. Os estoques de transferência do produto tiveram um enorme crescimento durante e após a safra de 1965/66. Pela primeira vez desde a década de 1930, os preços do açúcar diminuiram em termos relativos $e$ absolutos. Graças às reservas financeiras que haviam acumulado nos anos anteriores, a maioria dos usineiros conseguiu superar os piores efeitos da crise. $O$ mesmo náo se deu, entretanto, com os fornecedores de cana, responsáveis por uma parte do abastecimento da matéria-prima, muitos dos quais foram à falência e/ou tiveram que mudar de atividades. A despeito das salvaguardas previstas pela Estatuto da Lavoura Canavieira de 1943, criou-se uma situação de conflito entre eles e os usineiros. O relacionamento dessas duas categorias de produtores só voltaria a normalizar-se no final dos anos 60 , graças à recuperaçáo dos mercados internos e externos do açúcar.

\section{Concentração e Modernização do Setor (1969-1974)}

As políticas de promoção das exportaçōes têm sido um dos principais elementos das estratégias de desenvolvimento postas em prática pelos governos militares que se sucederam no poder entre 1968 e 1984 . Com uma intensidade variável, tais políticas já vinham sendo adotadas na agroindústria canavieira desde meados da década de 1950. Inicialmente, o propósito das mesmas fora tão somente o de romover, se necessário por meio de subsídios, toda a produção que não pudesse ser absorvida pelo mercado interno. Mais tarde, como mostramos há pouco, as exportações de açúcar foram assumindo uma crescente importância e um caráter mais permanente na expansão do setor, chegando até a tornar-se novamente, como no passado colonial, o principal fator do seu desenvolvimento. Entre os anos-safra de 1961/62 e 1971/72, o volume das exportaçōes de açúcar do Brasil aumentou quase $106 \%$, contra um crescimento de aproximadamente $50 \%$ na produçáo, e de apenas $38 \%$ no consumo interno do produto.

Para poder sustentar essa expansão, a agroindústria canavieira do país necessitava de um forte e contínuo apoio da parte do governo federal, apoio esse que the foi concedido de bom grado e formalmente através de três importantes programas de investimentos e de incentivos públicos: o Programa Nacional de Melboramento da Cana-de-Afuicar, que se tornaria mais conhecido através de sigla Planalsucar; o Programa 
de Racionalizagáo da Indústria Afucareira; e o Programa de Apoio d̀ Indistria Afucareira. Os dois primeiros foram instituídos em 1971, e o terceiro dois anos mais tarde, como substituto do segundo.

O principal objetivo do Planalsucar era o desenvolvimento em larga escala no país, e de acordo com as condiçóes e necessidades brasileiras, de novas variedades de cana por meio da experimentaçáo e da manipulação genéticas. Esse importante e de há muito necessário programa de pesquisa agronômica só veio a produzir seus primeiros resultados em monta no início da década de 1980 . Nos últimos anos, tadavia, a sua própria sobrevivência tem sido repetidamente ameaçada pela profunda crise econômica, política e social que o Brasil vem atravessando.

Foram, porém, os outros dois programas que, desde o início, sempre estiveram mais próximos dos interesses imediatos dos usineiros do país. O propósito dos mesmo era o de promover o crescimento preferencial das unidades e das regiónes produtivas mais eficientes. A concentração das unidades industriais e das terras agrícolas em grandes estabelecimentos era um objetivo prioritário explícita e ativamente perseguido por eles, junto com o aumento da capacidade produtiva da agroindústria canavieira como um todo. De acordo com eles, a elevaçáo da produtividade do setor iria ser rapidamente alcançada através da obtenção de economias de escala. Todas as anteriores preocupaçóes e atitudes protecionistas do IAA em relação às unidades produtivas menores e aos produtores de açúcar menos eficientes foram assim inteiramente abandonadas.

Como seria de se esperar, esses estímulos foram muito bem recebidos pelos usineiros, e muitos deles, particularmente em Sáo Paulo e em Alagoas, logo se candidataram à concessão dos fundos públicos então disponíveis. No início da década de 1970 , esses recursos eram bastante abundantes e tinham também um custo muito baixo para os seus recipientes, principalmente tendo em vista o processo inflacionário. Os subsídios oferecidos chegavam a constituir um verdadeiro presente.

A boa performance inicial dos três programas foi possibilitada especialmente pelos crescentes volumes e valores das exportaçōes brasileiras de açúcar. Estas, por sua vez, foram viabilizadas pelo aumento da demanda e dos preços nos mercados internacionais. Em 1971, o Brasil conseguiu exportar nada menos que 1,2 milhāo de TM de açúcar (20 milhóes de sacos de 60 quilos), um volume equivalente a quase $6 \%$ do consumo mundial do produto, graças a uma conjuntura de decréscimo temporário das safras de Cuba e da Europa Oriental. Devido a tal decréscimo, vários países daquela região, a começar pela URSS, tiveram que se abastecer no mercado livre mundial, elevando desta forma tanto a sua demanda como os seus preços. 
Devido aos estoques que acumulara por força da superprodução de anos anteriores, e por causa da disponibilidade de uma ampla capacidade ociosa em sua agroindústria canavieira, o Brasil era na época um dos poucos países do mundo capazes de responder imediatamente a esses estímulos repentinos dos mercados internacionais do açúcar. Em 1973, o país exportou quase três milhóes do produto, num valor total de US\$ 600 milhöes. Tratava-se de eventos extremamente auspiciosos para as finanças do IAA.

O monopólio das exportaçóes brasileiras de açúcar constituía uma atribuição do Instituto desde a década de 1930. Tratava-se de uma situaçáo muito conveniente para a agroindústria canavieira do país nas épocas de baixos preços nos mercados internacinais, épocas essas que são usualmente as mais frequientes. Mas, no início da década de 1970 , ao deixar de trasferir para o setor a totalidade de seus ganhos com as exportaçōes (resultantes da diferença entre os preços pagos aos produtores e os recebidos no exterior), o IAA conseguiu, pela primeira vez em sua história, acumular um ponderável excedente financeiro, a maior parte do qual foi canalizado para o custeio dos três programas de desenvolvimento setorial mencionados há pouco.

Apenas um desses programas, o Planalsucar, tinha um prazo de maturação mais longo (por causa da demora inerente ao processo de criaçáo de novas variedades de cana); os outros dois estavam promovendo, a curto e médio prazos, um substancial aumento da produçáo brasileira de açúcar, bem como uma ponderável ampliação da capacidade produtiva da agroindústria canavieira no país.

Um crescimento contínuo da produçáo e das exportaçōes só pode ser sustentado quando e enquanto as condiçóes de mercado seguirem melhorando ou, pelo menos, se mantiverem inalteradas. Como seria de esperar face à experiência histórica do setor, a situação então prevalecente nos mercados internacionais do açúcar náo poderia durar muito, como de fato náo durou. $O$ declínio veio repentinamente e com grande intensidade no início de 1975 . Os preços do produto alcançaram seu nível máximo nas bolsas internacionais de mercadorias em novembro de 1974: US\$ 1.388,56 por TM (ou US\$ 0,62 por libra-peso). Seis meses mais tarde, eles estavam reduzidos a US\$ 336,12 e, desde entáo, têm oscilado em torno de US $\$ 300,00$ por tonelada (ou US\$ 0,15 por librapeso).

O valor das exportaçóes brasileiras de açúcar estava sujeito a declinar fortemente nos anos seguintes. Mas, o pior aspecto dessa situaçăo era o fato de que o setor canavieiro se viu novamente enredado numa ampla crise de superprodução. E esta certamente teria eclodido na época se os "choques" no mercado internacional de petróleo e a decisáo do governo federal de promover um grande aumento da produção de ál- 


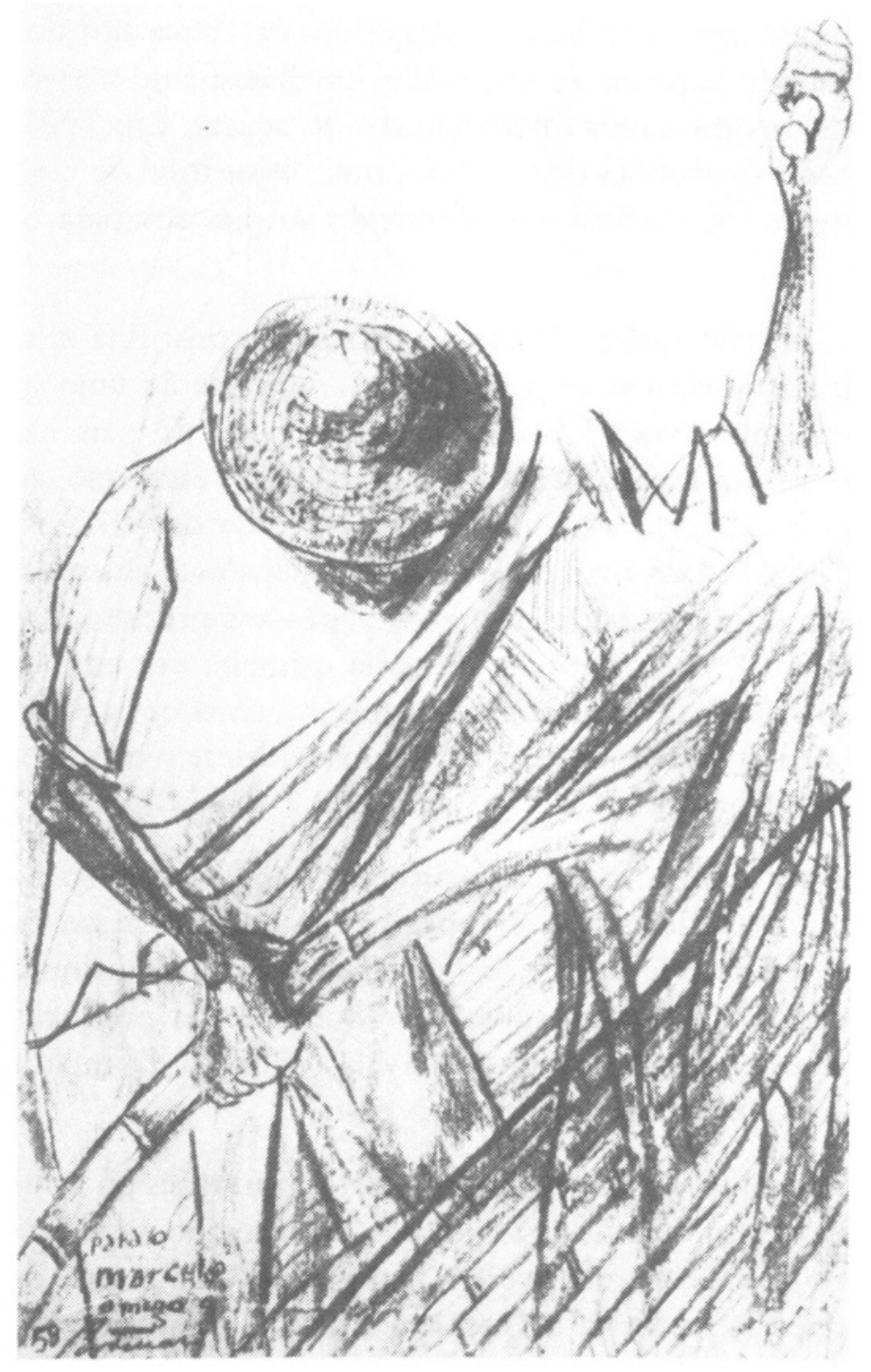

Nos primeiros dez anos de existência do Prod́lcool, a produção brasileira de álcool aumentou a uma taxa média de 35\% ao ano, sem que o setor deixasse de produzir polumosas quantidades de açicar, tanto para a exportafão como para 0 mercado interno

cool combustível não tivesse vindo a socorrer os usineiros brasileiros. Contudo, como se mostrará daqui a pouco, principalmente por causa das políticas excessivamente protecionistas que foram adotadas pelo Governo, os efeitos dessa crítica situaçáo da agroindústria canavieira do Brasil foram apenas adiados, mas não evitados ou superados por suas medidas.

\section{Do Açúcar para o Álcool e Vice-Versa (1975-1989)}

Já em meados de 1975, preocupado com os riscos de uma superprodução de açúcar e de cana, o IAA havia promovido uma substancial elevação dos preços pagos aos produtores, ao cstabelecer uma taxa de conversão de 44 litros de álcool por saco de açúcar de 60 quilos. Esse 
incentivo fora adotado para estimular os produtores a canalizarem toda a matéria-prima disponível para a fabricação de álcool "direto", em vez de destiná-lo à produção habitual de açúcar acrescido do álcool "residual" derivado do melaço. Mas, a medida mais importante foi adotada em novembro daquele ano, com a criação do Progrma Nacional do Álcool, ou Proálcool.

A justificativa oficial para o aumento da produção de álcool era a necessidade do país vir a encontrar um sucedâneo viável para a gasolina automotiva, com o objetivo de aliviar as pressões sobre a balança comercial ocasionadas pela elevaçăo dos preços internacionais do petróleo, que era então ainda preponderantemente importado. Embora várias outras matérias-primas (como a mandioca, a madeira, o babaçú e a batata doce) fossem mencionadas na época para esse propósito, a cana-de-açúcar facilmente iria conseguir manter sua condição privilegiada nesse mistér. Disto se pode concluir que o Programa do Álcool fora formulado e estabelecido menos como uma soluçáo para a "crise energética" do Brasil, do que como uma alternativa para a previsível capacidade ociosa da sua agroindústria canavieira.

No plano institucional, o governo brasileiro criou uma Comissão Nacinal do Álcool, formada por representantes dos vários ministérios envolvidos no Programa, enquanto que a Petrobrás recebeu a incumbência de absorver e distribuir a totalidade da produção de álcool combustível. Ao mesmo tempo foram criadas linhas de crédito especiais para a instalação e ampliaçăo de destilarias vinculadas a usinas de açúcar, as chamadas destilarias anexas, bem como para a construção de novas unidades produtivas independentes das mesmas e especializadas na produção de álcool, as destilarias autônomas. As condiçōes para a concessão desses financiamentos, parcialmente custeados por empréstimos externos (inclusive do Banco Mundial), eram extremamente favoráveis para os que quisessem valer-se deles, com taxas subsidiadas de juros e de correção monetária, cujos níveis eram muito inferiores aos da inflaçáo da época e, principalmente, dos anos posteriores.

A resposta a esses incentivos foi um crescimento muito rápido da produção de álcool, especialmente do álcool anidro adicionado à gasolina. Esse aumento, de mais de $\mathbf{5 0 \%} \mathrm{em}$ cinco anos, decorreu não apenas da plena utilização da capacidade instalada da agroindústria canavieira, mas também da sua expansão para além dos níveis alcançados na primeira metade da década de 1970. Uma outra importante conseqüência das medidas então adotadas pelo governo federal foi a ampliação da diferença entre os volumes de produçáo do Centro-Sul e do Nordeste. O Estado de São Paulo, em particular, distanciou-se muito do resto do país: às vésperas do Proálcool cle já era responsável por metade da produçáo brasileira de açúcar, após o início do programa passou a concen- 
trar também dois terços da produção de álcool. E outros estados da mesma região, até então sem grande tradiçăo na produçăo açucareira como Paraná, Goiás e Mato Grosso - também começaram a expandir suas culturas de cana (principalmente para produzir álcool), contribuindo desta maneira para reduzir ainda mais a participação no mercado interno dos produtores do Nordeste.

Com o segundo choque do petróleo em 1979, as autoridades brasilerias decidiram lançar um novo e ainda mais ambicioso programa de produção de álcool, que ficaria conhecido como "fase 2" do Proálcool. Sua principal meta quantitativa era o atingimento de uma produçáo de 10,7 bilhóes de litros em 1975, mas os seus aspectos qualitativos eram muito mais importantes. Através desse novo programa, a ênfase anterior na produçáo do álcool anidro, a ser utilizado como aditivo à gasolina, foi trocada por uma ênfase na produçao de álcool hidratado, o qual seria usado com combustível exclusivo em substituição à mesma.

A fim de garantir a consecuçáo deste último objetivo, um novo mercado teria que ser criado para o referido combustível. Isto foi feito, em primeiro lugar, mediante um acordo com a indústria automobilística, que, em troca de incentivos fiscais para a aquisiçáo dos seus produtos, aquiesceu em passar a produzir carros equipados com motores a álcool. Em segundo lugar, os preços ao consumidor do álcool hidratado foram fixados num nível equivalente a $65 \%$ dos da gasolina, apesar dos custos de produção muito inferiores desta última. Ao mesmo tempo, no lado da própria produção, a taxa de conversão do açúcar em álcool foi tornada ainda mais favorável do que antes (passando a 38 litros por saco de açúcar de 60 quilos), enquanto que as linhas de crédito subsidiado continuaram a ser mantidas, apesar da intensificaçáo do processo inflacionário.

Todas essas condiçōes extremamente vantajosas capacitaram a agroindústria canavieira do Brasil a rapidamente alcançar e ultrapassar as metas de produçáo governamentais. Nos primeiros dez anos de existência do Proálcool, a produçáo brasileira de álcool aumentou a uma taxa média de $35 \%$ ao ano, sem que o setor deixasse de produzir volumosas quantidades de açúcar, tanto para a exportação como para o mercado interno. Uma táo rápida expansáo só era possível à custa de grandes e graves distorçóes. No plano agrícola, ela provocou o excessivo crescimento de uma monocultura cheia de riscos, bem como uma exagerada concentração fundiária, extremamente deletéria do ponto de vista social. Mas, os seus efeitos no plano energético acabaram sendo talvez ainda mais destrutivos, levando a agroindústria canavieira a um confronto direto, primeiro com a Petrobrás, depois com o Governo e, final- 
mente, com os três interesses econômicos da sociedade brasileira como um todo.

Durante a década de 1979 a 1989 , os preços internacionais do petróleo diminuíram substancialmente, permanecendo muito abaixo dos níveis vigentes no iníco daquele período. Ao mesmo tempo, o Brasil foi se tornando cada vez mais autosuficiente nesse produto, reduzindo as suas importaçóes do mesmo para menos que $40 \%$ dos seus níveis de consumo corrente. Com isso, o Programa do Álcool foi se tornando cada vez mais caro e menos necessário para o país.

Além disso, desde a época do primeiro choque no mercado internacional do petróleo, a Petrobrás vinha se esforçando em manter relativamente mais baixos os preços de alguns derivados considerados estratégicos do ponto de vista social - como o óleo diesel, muito utilizado no transporte predominantemente rodoviário do país; o gás liquefeito de petróleo (GLP) de vasto uso doméstico, o querosene para aviação; $e$ a nafta para fins petroquímicos. Em compensaçáo cobrava mais por bens de consumo de menor essencialidade, como a gasolina automotiva. Essa política e a estrutura de preços dela resultante começaram a ruir no início da década de 1980, à medida que o álcool hidratado foi se apropriando de crescentes parcelas do mercado da gasolina, aumentando o volume dos excedentes desse produto que deveriam ser exportados pela Petrobrás a preços muito inferiores aos do mercado interno. Tais exportaçóes forçadas e gravosas, somadas aos prejuízos inerentes à comercialização do álcool hidratado, contribuiram poderosamente para enfraquecer a outrora próspera situação financeira daquela empresa estatal, bem como a do próprio governo federal. Este não apenas cessou de receber diversos tributos anteriormente incidentes sobre os automóveis e os combustíveis líquidos, como freqüentemente passou a ser obrigado a transferir recursos do Tesouro para os fundos requeridos pela manutençăo dos diferenciais de preços (pagos e recebidos) do Proálcool.

Embora tivesse ficado claro, em meados da década de 1980, que tanto o consumo como a produção do álcool hidratado deveriam ser contidos dentro de certos limites, a fim de garantir a sobrevivência, não da Petrobrás ou do Governo, mas do Proálcool e da própria agroindústria canavieira, absolutamente nada chegou a ser feito nessa direção. A situaçáo que acaba de ser descrita manteve-se inalterada - ou melhor, foi se agravando paulatinamente - até janeiro de 1989, quando, finalmente, o diferencial de preços entre a gasolina e o álcool hidratado foi reduzido dos anterioes $35 \%$ para $25 \%$. Apesar de que este último nível ainda esteja longe de refletir a defasagem dos custos de produçáo desses dois combustiveis (já que os da gasolina continuam sendo mais baixos que os do álcool), e embora os carros a álcool tivessem continuado a manter a gasolina, a mudança foi suficiente para alertar os compradores 
de carros novos, e para fazer reverter a preferência dos consumidores aos produtos tradicioais da indústria automobilística.

Ultimamente, essa preferência acabou sendo acentuada por uma crescente e paradoxal escassez de álcool no país. Essa nova e inesperada situação decorreu, de um lado, das crescentes dificuldades da Petrobrás, as quais levaram essa companhia estatal primeiro a retardar seus pagamentos aos produtores de álcool, e em seguida a abandonar a estocagem de reservas do produto. Os estoques em questáo eram (e são) indispensáveis porque o Brasil é o maior produtor mundial de álcool, e pelo fato deste não chegar ainda a ser transacionado em grandes quantidades nos mercados internacionais. Mas, por outro lado, a referida situaçáo foi também devida a uma opçáo consciente de muitos produtores, que, deliberadamente, passaram a diminir a sua produçáo de álcool, ou a deixar de entregá-la à Petrobrás, comercializando-o diretametne junto aos postos de gasolina do interior (o chamado álcool clandestino), ou, no caso das usinas, que voltaram a priorizar a produçáo de açúcar, tendo em vista eventuais aumentos de preços nos mercados externos e a entáo anunciada retirada do monopólio das exportaçóes do produto das máos do IAA.

Em março de 1990, o próprio Instituto acabou sendo fechado. Mesmo assim, a atitude dos produtores de álcool parece excessivamente imediatista, envolvendo o risco de alienar definitivametne um mercado até agora garantido, através da perda de confiança dos consumidores quanto à disponibilidade do álcool, e no que se refere às vantagens de possuir ou de comprar automóveis baseados no uso desse combustível. O eventual colapso da demanda de álcool hidratado só contribuiria para aumentar ainda mais o caráter insolúvel e inescapável da crise de superprodução que tem ameaçado a agroindústria canavieira do Brasil nestas últimas décadas. Embora as causas dessa crise já sejam agora bastante conhecidas, os seus resultados e principais conseqüências continuam sendo difíceis de prever. Isto porque eles passaram a depender, não mais apenas da atuação e das reaçóes dos principais grupos envolvidos, mas dos interesses e do posicionamento da sociedade brasileira como um todo.

\section{Notas}

1 Os problemas mencionados neste parágrafo foram anteriormente discutidos num trabalho ainda inédito - Tamás Szmrcesányi, "Concurrence et complémentarirés dans la Filière Sucre", apresentado em dezembro de 1988 nas IVimes Rencontres Internatinales d'Agropolis, em Montpellier (França); e na comunicaçăo de T. Szmrecsányi e L. C. Guarnieri, "Some socio-economic aspects of the National Alcohol Programin Brazil", apre- 
sentado em setembro de 1990 no First World Renewable Energy Congress promovido pela Universidade de Reading (Inglaterra). Este último trabalho acha-se publicado em A. A. M. Sayigh (ed.), Energy and the Environment into the 1990s (Oxford, 1990, Pergamon Press), vol. 5, pp. 2986-2990.

2 Tamás Szmrecsányi, "Growth and crisis of the Brazilian Sugar Industry, 1914-39", apresentado na conferência Crisis and Change in the International Sugar Economy, 1914-1945 and the 1980s, realizada na Universidade de East Anglia, em Norwich (Inglaterra), em setembro de 1986. Versōes resumidas desse trabalho foram publicadas em Bill Albert \& Adrian Graves (eds.), The world Sugar Economy in War and Depression, 1914-40 London, 1988, Routledge), pp. 59-70; e na Rivista di Storia Economica, N. S., 5(2), Mai/Ago.1988, pp. 193-219. O texto completo foi publicado em português na Revista Brasileira de Ciênians Sociais, $3(7), j^{\prime}{ }^{\prime} \cdot 1.1988$, pp. 42-68; e em espanhol da revista HISLA de Lima (Peru), $n^{\circ}$ XI, $1^{\circ}$ semestre de 1988, pp. 45-79.

3 Tamás Szmrecsányi, O Planejamento da Agroindístria Canavicira do Brasil (1930-1975) (São Paulo, 1979, Editora Hucitec), 540 págs.; e Eduardo F. P. Moreira, Expansão, Concentraf̧ão e Concorrência na Agroinduistria Canavieira em Säo Paulo, 1975 a 1987 (Campinas, 1989, Instituto de Economia da UNICAMP), dissertação de mestrado mimeogr., $132 \mathrm{pp}$.

\section{Resumo}

Avaliaçăo do desenvolvimento da produçăo brasileira de cana, açúcar e álcool nos últimos 50 anos, bem como das mudanças de sua distribuição espacial após a Segunda Guerra. Retrospecto cronológico dos principais problemas da agroindústria canavieira cobrindo quatro períodos sequenciais (1939-1949), tentativas de reinserção do Brasil nos mercados açucareiros internacionais (1950-1968), tendências de concentração e de mordernização setoriais (1969-1974), os desvios do açúcar para o álcool e vice versa. O artigo termina com algumas breves consideraçóes sobre a crise da oferta de álcool em 1990.

\footnotetext{
Abstract

Assessmente of the crolution of Brazil 's sugarcane, sugar and ethanol production durng the alst fifty years, as well as of its shiffing spatial pattern after the last World War., Chronological account ofthe industry's main problems covering four sequential periods: World War II and its consequences (1939-1949), attempts of reinsertion in the international sugar markets (1950-1968), trends of sectorial concentration and modernization (1969-1974), and dislocations from sugar to ethanol and vice versa (1975-1989). The article ends with some succint considerations on the ethanol supply crisis of 1990.
} 
Anexos

\begin{tabular}{|c|c|c|c|}
\hline \multicolumn{4}{|c|}{ I - Produçäo Brasileira de Cana-de-Açucar (em milhares) } \\
\hline $\begin{array}{l}\text { Anos-Safra } \\
\text { (hectares) }\end{array}$ & $\begin{array}{l}\text { Superficies } \\
\text { (TM) }\end{array}$ & $\begin{array}{l}\text { Quantidades } \\
\text { (tons/hectare) }\end{array}$ & Rendimentos \\
\hline $\begin{array}{l}1939 / 40 \\
1940 / 41 \\
1941 / 42 \\
1942 / 43 \\
1943 / 44 \\
1944 / 45 \\
1945 / 46 \\
1946 / 47 \\
1947 / 48 \\
1948 / 49\end{array}$ & $\begin{array}{l}482 \\
515 \\
560 \\
559 \\
577 \\
676 \\
657 \\
758 \\
773 \\
819 \\
\end{array}$ & $\begin{array}{l}19.514 \\
21.475 \\
21.463 \\
21.574 \\
22.051 \\
25.149 \\
25.179 \\
28.069 \\
28.990 \\
30.893 \\
\end{array}$ & $\begin{array}{l}40,5 \\
41,7 \\
38,3 \\
38,6 \\
38,2 \\
37,2 \\
38,3 \\
37,0 \\
37,5 \\
37,7 \\
\end{array}$ \\
\hline $\begin{array}{l}1949 / 50 \\
1950 / 51 \\
1951 / 52 \\
1952 / 53 \\
1953 / 54 \\
1954 / 55 \\
1955 / 56 \\
1956 / 57 \\
1957 / 58 \\
1958 / 59\end{array}$ & $\begin{array}{l}797 \\
828 \\
874 \\
920 \\
991 \\
1.027 \\
1.073 \\
1.124 \\
1.172 \\
1.208\end{array}$ & $\begin{array}{l}30.929 \\
32.671 \\
33.653 \\
36.041 \\
38.337 \\
40.302 \\
40.946 \\
43.976 \\
47.703 \\
50.019\end{array}$ & $\begin{array}{l}38,8 \\
39,5 \\
38,5 \\
39,2 \\
38,7 \\
39,2 \\
38,2 \\
39,1 \\
40,7 \\
41,4\end{array}$ \\
\hline $\begin{array}{l}1959 / 60 \\
1960 / 61 \\
1961 / 62 \\
1962 / 63 \\
1963 / 64 \\
1964 / 65 \\
1965 / 66 \\
1966 / 67 \\
1967 / 68 \\
1968 / 69\end{array}$ & $\begin{array}{l}1.291 \\
1.361 \\
1.367 \\
1.467 \\
1.509 \\
1.519 \\
1.705 \\
1.636 \\
1.681 \\
1.687\end{array}$ & $\begin{array}{l}\mathbf{5 3 . 4 7 7} \\
\mathbf{5 7 . 1 7 8} \\
\mathbf{5 9 . 3 7 8} \\
\mathbf{6 2 . 5 3 5} \\
\mathbf{6 3 . 7 2 3} \\
\mathbf{6 6 . 3 9 9} \\
\mathbf{7 5 . 8 5 3} \\
\mathbf{7 5 . 7 8 8} \\
\mathbf{7 7 . 0 8 7} \\
\mathbf{7 6 . 6 1 0}\end{array}$ & $\begin{array}{l}41,4 \\
42,0 \\
43,4 \\
42,6 \\
42,2 \\
43,7 \\
44,4 \\
46,3 \\
45,9 \\
45,4\end{array}$ \\
\hline $\begin{array}{l}1969 / 70 \\
1970 / 71 \\
1971 / 72 \\
1972 / 73 \\
1973 / 74 \\
1974 / 75 \\
1975 / 76 \\
1976 / 77 \\
1977 / 78 \\
1978 / 79 \\
\end{array}$ & $\begin{array}{l}1.672 \\
1.725 \\
1.692 \\
1.541 \\
1.644 \\
1.721 \\
1.933 \\
2.032 \\
2.176 \\
2.369 \\
\end{array}$ & $\begin{array}{r}75.247 \\
79.753 \\
79.595 \\
67.870 \\
75.839 \\
74.509 \\
68.513 \\
87.827 \\
104.634 \\
109.714 \\
\end{array}$ & $\begin{array}{l}45,0 \\
46,2 \\
47,0 \\
44,0 \\
46,1 \\
43,3 \\
35,4 \\
43,2 \\
48,1 \\
46,3\end{array}$ \\
\hline $\begin{array}{l}1979 / 8 \\
1980 / 81 \\
1981 / 82 \\
1982 / 83 \\
1983 / 84(+) \\
1984 / 85(+) \\
1985 / 86 \\
1986 / 87 \\
1987 / 88 \\
1988 / 89 \\
\end{array}$ & $\begin{array}{r}2.498 \\
2.767 \\
2.920 \\
3.362 \\
3.611 \\
3.878 \\
4.165 \\
3.951 \\
4.314 \\
\text { nd } \\
\end{array}$ & $\begin{array}{l}117.324 \\
132.063 \\
133.286 \\
166.856 \\
197.377 \\
202.618 \\
227.185 \\
227.876 \\
224.498 \\
221.339 \\
\end{array}$ & $\begin{array}{r}47,0 \\
49,4 \\
45,6 \\
49,6 \\
54,7 \\
52,2 \\
54,5 \\
57,7 \\
52,0 \\
\text { nd } \\
\end{array}$ \\
\hline \multicolumn{4}{|c|}{$\begin{array}{l}\text { nd = (nāo disponível) } \\
\text { Fontes: IAA (Anud́rios Afucarciros) até } 1965 \\
\text { IBGE (Anuários Estatísticos) depois disso. } \\
\text { Nota: (+) estimativas }\end{array}$} \\
\hline
\end{tabular}




\begin{tabular}{|c|c|c|c|c|}
\hline \multicolumn{5}{|c|}{ II - Produção e Exportaçōes de Açucar do Brasil (mil sacos de 60 quilos) } \\
\hline Anos-Safra & Produção & $\begin{array}{l}\text { Anos } \\
\text { Civis }\end{array}$ & Exportaçöes & $\begin{array}{c}\% \text { da } \\
\text { Produçāo }\end{array}$ \\
\hline $\begin{array}{l}1939 / 40 \\
1940 / 41 \\
1941 / 42 \\
1942 / 43 \\
1943 / 44 \\
1944 / 45 \\
1945 / 46 \\
1946 / 47 \\
1947 / 48 \\
1948 / 49\end{array}$ & $\begin{array}{l}14.406 \\
13.512 \\
13.839 \\
14.759 \\
15.134 \\
14.897 \\
15.418 \\
18.352 \\
22.623 \\
23.579\end{array}$ & $\begin{array}{l}1940 \\
1941 \\
1942 \\
1943 \\
1944 \\
1945 \\
1946 \\
1947 \\
1948 \\
1949\end{array}$ & $\begin{array}{r}1.100 \\
414 \\
165 \\
386 \\
963 \\
313 \\
171 \\
1.020 \\
5.693 \\
942\end{array}$ & $\begin{array}{r}7,6 \\
3,1 \\
1,2 \\
2,6 \\
6,4 \\
2,1 \\
1,1 \\
5,6 \\
25,2 \\
4,0\end{array}$ \\
\hline $\begin{array}{l}1949 / 50 \\
1950 / 51 \\
1951 / 52 \\
1952 / 53 \\
1953 / 54 \\
1954 / 55 \\
1955 / 56 \\
1956 / 57 \\
1957 / 58 \\
1958 / 59\end{array}$ & $\begin{array}{r}21.140 \\
24.817 \\
26.596 \\
30.802 \\
33.376 \\
\mathbf{3 5 . 5 6 8} \\
\mathbf{3 5 . 4 6 4} \\
\mathbf{3 7 . 5 8} \\
\mathbf{4 3 . 3 7 8} \\
\mathbf{5 3 . 8 5 9}\end{array}$ & $\begin{array}{l}1950 \\
1951 \\
1952 \\
1953 \\
1954 \\
1955 \\
1956 \\
1957 \\
1958 \\
1959\end{array}$ & $\begin{array}{r}400 \\
306 \\
722 \\
4.109 \\
2.509 \\
9.683 \\
390 \\
6.816 \\
12.930 \\
10.098\end{array}$ & $\begin{array}{r}1,9 \\
1,2 \\
2,7 \\
13,3 \\
7,5 \\
27,2 \\
1,1 \\
18,1 \\
29,8 \\
18,7\end{array}$ \\
\hline $\begin{array}{l}1959 / 60 \\
1960 / 61 \\
1961 / 62 \\
1962 / 63 \\
1963 / 64 \\
1964 / 65 \\
1965 / 66 \\
1966 / 67 \\
1967 / 68 \\
1968 / 69\end{array}$ & $\begin{array}{r}\mathbf{5 0 . 8 6 4} \\
\mathbf{5 4 . 3 5} \\
\mathbf{5 6 . 4 3 4} \\
\mathbf{5 1} .079 \\
\mathbf{5 1 . 6 4 5} \\
\mathbf{5 9 . 4 2 2} \\
\mathbf{7 5 . 9 8 2} \\
\mathbf{6 8 . 5 9 9} \\
\mathbf{7 0 . 2 6 1} \\
\mathbf{6 8 . 5 3 0}\end{array}$ & $\begin{array}{l}1960 \\
1961 \\
1962 \\
1963 \\
1964 \\
1965 \\
1966 \\
1967 \\
1968 \\
1969\end{array}$ & $\begin{array}{r}14.246 \\
12.414 \\
7.976 \\
8.193 \\
4.471 \\
13.779 \\
16.959 \\
16.848 \\
18.257 \\
18.045\end{array}$ & $\begin{array}{r}28,0 \\
22,8 \\
14,1 \\
16,0 \\
8,7 \\
23,2 \\
22,3 \\
24,6 \\
26,0 \\
26,3\end{array}$ \\
\hline $\begin{array}{l}1969 / 70 \\
1970 / 71 \\
1971 / 72 \\
1972 / 73 \\
1973 / 74 \\
1974 / 75 \\
1975 / 76 \\
1976 / 77 \\
1977 / 78 \\
1978 / 79\end{array}$ & $\begin{array}{r}72.216 \\
85.328 \\
89.774 \\
98.874 \\
111.382 \\
112.010 \\
98.126 \\
120.137 \\
138.46 \\
122.374 \\
\end{array}$ & $\begin{array}{l}1970 \\
1971 \\
1972 \\
1973 \\
1974 \\
1975 \\
1976 \\
1977 \\
1978 \\
1979 \\
\end{array}$ & $\begin{array}{l}19.165 \\
20.715 \\
43.917 \\
49.510 \\
38.378 \\
28.827 \\
20.873 \\
41.443 \\
32.077 \\
32.360 \\
\end{array}$ & $\begin{array}{l}26,5 \\
24,3 \\
48,9 \\
50,1 \\
34,5 \\
25,7 \\
21,3 \\
34,5 \\
23,2 \\
26,4 \\
\end{array}$ \\
\hline $\begin{array}{l}1979 / 80 \\
1980 / 81 \\
1981 / 82 \\
1982 / 83 \\
1983 / 84 \\
1984 / 85 \\
1985 / 86 \\
1986 / 87 \\
1987 / 88 \\
1988 / 89\end{array}$ & $\begin{array}{l}110.770 \\
135.005 \\
132.255 \\
147.619 \\
151.435 \\
147.481 \\
130.321 \\
135.953 \\
133.087 \\
134.503\end{array}$ & $\begin{array}{l}1980 \\
1981 \\
1982 \\
1983 \\
1984 \\
1985 \\
1986 \\
1987 \\
1988 \\
1989\end{array}$ & $\begin{array}{r}44.365 \\
44.501 \\
46.471 \\
46.677 \\
50.658 \\
43.478 \\
42.575 \\
40.401 \\
26.833 \\
\text { nd }\end{array}$ & $\begin{array}{r}40,1 \\
33,0 \\
35,1 \\
31,6 \\
33,5 \\
29,5 \\
32,7 \\
29,7 \\
20,1 \\
\text { nd }\end{array}$ \\
\hline $\begin{array}{l}\text { nd }=\text { (não } \\
\text { Fontes: IA }\end{array}$ & $\begin{array}{l}\text { Onível) } \\
\text { Codeplan }\end{array}$ & & & \\
\hline
\end{tabular}




\begin{tabular}{|c|c|c|c|}
\hline \multicolumn{4}{|c|}{ III - Produção Brasileira de Álenol (metros cúbicos) } \\
\hline Anos-Safra & $\begin{array}{l}\text { Álcool } \\
\text { Anidro }\end{array}$ & $\begin{array}{l}\text { Álcool } \\
\text { Hidratado }\end{array}$ & Total \\
\hline $\begin{array}{l}1939 / 40 \\
1940 / 41 \\
1941 / 42 \\
1942 / 43 \\
1943 / 44 \\
1944 / 45 \\
1945 / 46 \\
1946 / 47 \\
1947 / 48 \\
1948 / 49\end{array}$ & $\begin{array}{l}31.499 \\
67.599 \\
70.654 \\
76.952 \\
46.650 \\
30.422 \\
26.120 \\
36.103 \\
61.517 \\
75.126 \\
\end{array}$ & $\begin{array}{l}\mathbf{6 2 . 2 1 5} \\
\mathbf{5 9 . 0 2 2} \\
\mathbf{5 7 . 9 3 9} \\
\mathbf{7 4 . 7 8 7} \\
\mathbf{7 8 . 3 5 0} \\
\mathbf{8 9 . 3 4 8} \\
\mathbf{8 0 . 3 9 1} \\
\mathbf{8 0 . 9 3 4} \\
\mathbf{8 2 . 3 2 7} \\
\mathbf{9 2 . 2 0 6} \\
\end{array}$ & $\begin{array}{r}93.714 \\
126.621 \\
128.593 \\
151.739 \\
125.000 \\
119.770 \\
106.511 \\
117.037 \\
143.844 \\
167.332 \\
\end{array}$ \\
\hline $\begin{array}{l}1949 / 50 \\
1950 / 51 \\
1951 / 52 \\
1952 / 53 \\
1953 / 54 \\
1954 / 55 \\
1955 / 56 \\
1956 / 57 \\
1957 / 58 \\
1958 / 59 \\
\end{array}$ & $\begin{array}{r}30.600 \\
28.416 \\
47.997 \\
99.154 \\
144.506 \\
168.490 \\
165.837 \\
104.409 \\
245.098 \\
281.728 \\
\end{array}$ & $\begin{array}{l}105.049 \\
111.679 \\
122.365 \\
130.389 \\
129.533 \\
137.756 \\
117.352 \\
147.976 \\
153.719 \\
162.521 \\
\end{array}$ & $\begin{array}{l}135.649 \\
140.095 \\
170.362 \\
229.543 \\
274.039 \\
306.246 \\
283.189 \\
252.385 \\
398.817 \\
444.249 \\
\end{array}$ \\
\hline $\begin{array}{l}1959 / 60 \\
1960 / 61 \\
1961 / 62 \\
1962 / 63 \\
1963 / 64 \\
1964 / 65 \\
1965 / 66 \\
1966 / 67 \\
1967 / 68 \\
1968 / 69 \\
\end{array}$ & $\begin{array}{r}302.160 \\
175.289 \\
206.196 \\
101.143 \\
96.090 \\
110.232 \\
336.274 \\
382.128 \\
358.496 \\
143.309 \\
\end{array}$ & $\begin{array}{l}169.885 \\
281.013 \\
221.324 \\
242.575 \\
309.387 \\
276.731 \\
266.433 \\
345.351 \\
317.766 \\
330.336\end{array}$ & $\begin{array}{l}472.045 \\
456.302 \\
427.520 \\
343.718 \\
405.477 \\
386.963 \\
602.707 \\
727.479 \\
676.262 \\
473.645\end{array}$ \\
\hline $\begin{array}{l}1969 / 70 \\
1970 / 71 \\
1971 / 72 \\
1972 / 73 \\
1973 / 74 \\
1974 / 75 \\
1975 / 76 \\
1976 / 77 \\
1977 / 78 \\
1978 / 79\end{array}$ & $\begin{array}{r}100.444 \\
252.397 \\
389.948 \\
388.891 \\
306.215 \\
216.528 \\
232.621 \\
300.340 \\
1.176 .948 \\
2.095 .597\end{array}$ & $\begin{array}{l}361.165 \\
384.841 \\
223.120 \\
292.081 \\
359.763 \\
408.457 \\
323.006 \\
363.682 \\
293.456 \\
395.006\end{array}$ & $\begin{array}{r}461.609 \\
637.238 \\
613.068 \\
680.972 \\
665.978 \\
624.985 \\
555.627 \\
664.022 \\
1.470 .404 \\
2.490 .603\end{array}$ \\
\hline $\begin{array}{l}1979 / 80 \\
1980 / 81 \\
1981 / 82 \\
1982 / 83 \\
1983 / 84 \\
1984 / 85 \\
1985 / 86 \\
1986 / 87 \\
1987 / 88 \\
1988 / 89\end{array}$ & $\begin{array}{l}2.713 .360 \\
2.104 .027 \\
1.453 .098 \\
3.549 .705 \\
2.469 .443 \\
2.102 .585 \\
3.201 .271 \\
2.168 .301 \\
1.982 .715 \\
1.726 .283\end{array}$ & $\begin{array}{r}683.095 \\
1.602 .348 \\
2.787 .025 \\
2.273 .634 \\
5.394 .768 \\
7.148 .967 \\
8.619 .169 \\
8.369 .083 \\
9.475 .892 \\
9.996 .655\end{array}$ & $\begin{array}{r}3.390 .455 \\
\mathbf{3 . 7 0 6 . 3 7 5} \\
4.240 .123 \\
\mathbf{5 . 8 2 3 . 3 3 9} \\
7.864 .211 \\
9.251 .552 \\
11.820 .440 \\
10.537 .384 \\
11.458 .607 \\
11.722 .938\end{array}$ \\
\hline \multicolumn{4}{|c|}{ Fontes: IAA/Codeplan } \\
\hline
\end{tabular}




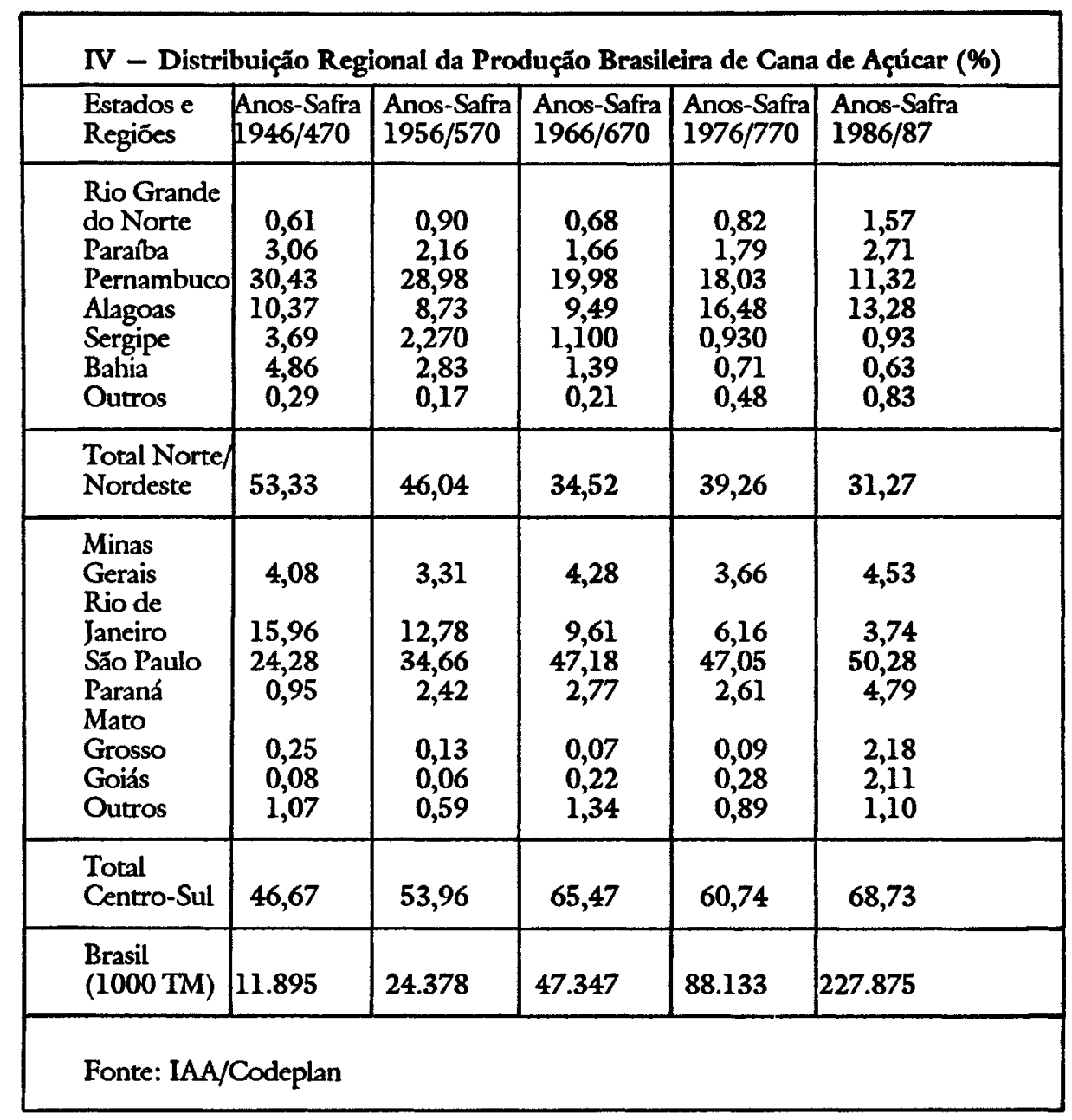

